\title{
SISTEM APLIKASI "PINDA" UNTUK MENCARI CONTENT CREATOR MENGGUNAKAN METODE SCRUM
}

\author{
Bimo Fikri Wicaksono ${ }^{1}$, Mukhlish Ibadurrahman ${ }^{2}$, Ricky Ariansyah ${ }^{3}$, Inge Handriani ${ }^{4}$ \\ ${ }^{1234}$ Jurusan Sistem Informasi-Fakultas Ilmu Komputer/Universitas Mercu Buana \\ JL. Meruya Selatan No.1, Meruya Selatan, Kembangan, Jakarta Barat \\ 141815110094@student.mercubuana.ac.id, 241815110141@student.mercubuana.ac.id, \\ 341815110134@student.mercubuana.ac.id, ${ }^{4}$ inge.handriani@mercubuana.ac.id
}

\begin{abstract}
Abstrak-Pekerjaan merupakan salah satu aktifitas yang paling utama dilakukan oleh manusia dan dewasa ini seiring dengan perkembangan teknologi informasi khususnya sosial media, menciptakan sebuah peluang besar bagi para pekerja kreatif salah satunya yaitu content creator. Banyaknya minat akan jasa content creator tidak sebanding dengan kemudahan dalam menemukan jasa content creator ini, sehingga hal ini cukup menyulitkan pemilik proyek apabila mereka ingin menggunakan jasa tersebut dan disisi lain hal ini juga merugikan para content creator pemula untuk mendapatkan informasi mengenai proyek yang sesuai dengan bidang mereka. Pengembangan aplikasi sistem ini menggunakan pendekatan model Scrum yang dimulai dengan penyusunan backlog product dan kemudian dilanjutkan dengan kegiatan sprint backlog yang sudah ditentukan estimasi waktu pengerjaannya, serta menggunakan metode PIECES sebagai dasar untuk melakukan Analisa permasalahan yang ada. Oleh karena itu aplikasi sistem PINDA akan membantu memberikan solusi dalam pencarian kerja bagi Content Creator.
\end{abstract}

Keywords-Content Creator, Pencari Kerja, Aplikasi Sistem, Pekerja Kreatif.

Abstract-Work is one of the most important activities carried out by humans and today along with the development of information technology specifically social media, creating a large for creative workers one of whom is content creator. Many interest in content creators is not worth the convenience of finding these content creators, so this makes it quite difficult for project owners to encourage them to use these services as well as other things that are also related to content creators who want to get information about projects that suit their fields . Developing this system application uses the Scrum model which starts with gathering a product backlog and then starts with a predetermined sprint backlog activity, calculates the processing time, and uses the PIECES method as a basis for analyzing existing. Therefore the PINDA system application will help provide solutions in job search for Content Creators.

Keywords - Content Creators, Job Seekers, System Applications, Creative Workers.

\section{PENDAHULUAN}

Di Indonesia, mencari pekerjaan bukan lagi hal yang mudah, hal ini disebabkan oleh ketidakseimbangan antara lapangan pekerjaan dengan banyaknya pencari pekerja. Persaingan yang ketat membuat setiap orang harus meningkatkan kualitas diri yang dimiliki, hal ini juga menjadi perhatian dalam pencarian tenaga kerja di beberapa negara ASEAN [1] . Meningkatkan kualitas diri bisa dari berbagai aspek, namun yang menjadi sorotan utama saat ini yaitu pendidikan dan keahlian. Semakin tinggi jenjang pendidikan yang dimiliki oleh seseorang, maka peluang untuk mendapatkan pekerjaan akan meningkat, karena faktor penting investasi sumber daya manusia yaitu pendidikan [2]. Namun, pendidikan pun saat ini tidak menjamin seseorang untuk mendapatkan pekerjaan, keterampilan yang dimiliki oleh seseorang akan menjadi nilai lebih dalam mencari pekerjaan, karena tingginya produktivitas kerja dipengaruhi oleh keterampilan kerja yang dimiliki oleh seseorang [3].
Saat ini, penggunaan teknologi informasi khususnya social media sedang meningkat pesat, hal ini di buktikan melalui hasil survei yang dilakukan pada bulan Januari 2017 dimana Indonesia menempati peringkat ketiga sebagai pengguna sosial media terbesar didunia [4]. Namun saat ini social media tidak hanya digunakan untuk berinteraksi saja, melainkan sudah digunakan untuk berbisnis, berpromosi, berkarir, membangun identitas diri dan lain sebagainya [5], suatu organisasi dapat menggunakan teknologi ini secara efektif dan efisien guna mendukung kegiatan mereka [6]. Berdasarkan survei emarketer, media social yang sering digunakan saat ini yaitu Facebook dan Instagram dengan perolehan $87,5 \%$ untuk tren penggunaan Facebook dan 69,2\% untuk tren penggunaan Instagram [7]. Fenomena ini menimbulkan banyaknya lapangan pekerjaan baru yang terbuka, namun masyarakat dituntut lebih kreatif untuk bisa bersaing didunia digital khususnya sosial media, karena secara simultan, inovasi dan kreatifitas mempunyai pengaruh yang signifikan terhadap kinerja karyawan [8]. Oleh karena itu, pekerjaan sebagai seorang content creator banyak dicari untuk membuat konten dimedia sosial yang 
menarik, karena untuk menarik minat pembaca dan pemasangan iklan, perusahaan wajib melakukan inovasi [9].

Content creator merupakan suatu profesi yang membuat sebuah konten pada suatu media baik itu berupa gambar, suara, tulisan, video ataupun gabungan dari beberapa materi. Semakin menarik konten yang dibuat dan semakin dekat isi konten tersebut dengan masyarakat, maka minat masyarakat untuk melihat promosi atau iklan tersebut akan semakin besar, karena menurut observasi yang ditelah dilakukan oleh Tresna Ferdiana, sebanyak 78,4 masyarakat terganggu dengan kemunculan iklan komersial baik secara konten dan penayangan di media konvensional ataupun digital [10].

Atas dasar alasan tersebut, dewasa ini mulai muncul platform - platform untuk mencari seseorang yang berprofesi sebagai pembuat konten. Aplikasi perekrutan berbasis web bisa dijadikan solusi untuk perekrutan dalam perusahaan [11], karena perkembangan teknologi sudah digunakan luas karena mampu menyediakan informasi yang cepat, tepat dan akurat [12]. Platform yang biasa digunakan saat ini yaitu LinkedIn dan Kontenesia.com. Melalui LinkedIn, pemilik bisnis bisa mencari seorang content creator yang sekiranya sesuai dengan karakter yang dimiliki oleh pemilik bisnis yang ingin dipromosikan. Sedangkan Kontenesia.com merupakan sebuah agensi yang bergerak dibidang kreatif yang siap membantu pemilik bisnis dalam membuat sebuah konten. Melalui platform tersebut diharapkan perusahaan tidak lagi menggunakan media cetak sebagai sarana informasi lowongan kerja [13]. Berdasarkan beberapa platform yang menyediakan fasilitas pencarian kerja, masih memiliki banyak kekurangan informasi berkaitan dengan spesifikasi pekerjaan sehingga content creator tidak memiliki banyak pilihan pekerjaan dan dari sisi yang menawarkan proyek tidak memperoleh informasi detail mengenai data content creator sesuai dengan kebutuhan. Oleh karena itu, pada penelitian ini menggabungkan cara kerja kedua platform tersebut dalam sebuah program dimana pemilik proyek bisa mempublikasikan proyek yang ingin mereka buat dan content creator bisa bergabung kedalam proyek sesuai dengan kebutuhan dilapangan.

Untuk membuat sistem aplikasi tersebut, penelitian ini menggunakan metode scrum sebagai metode pengembangan sistem. Scrum dipilih karena dinilai sesuai untuk ukuran tim yang kecil dan seiring proses pengembangan banyak terjadi perubahan [14]. Lalu metode PIECES digunakan untuk mengidentifikasi dan memecahkan permasalahan yang ada guna mendapatkan solusi atas masalah tersebut [15]. Hasil penelitian ini merupakan aplikasi pertama yang khusus dibuat untuk bidang content creator dengan fitur mulai dari input portofolio content creator, input proyek oleh pemilik proyek, hingga pembayaran. Penelitian ini mengkaji berkaitan dengan pencarian content creator untuk sosial media.

\section{METODE PENELITIAN}

Penelitian ini dilakukan di wilayah Bandung dan Kota Tangerang dengan ruang lingkup profesi sebagai content creator dan pemilik usaha dengan sarana pendukung yang terdiri dari perangkat keras (Hardware) dan perangkat lunak (Software) dan mengacu pada suatu diagram alir yang dibuat untuk membangun sistem aplikasi.

Teknik pengumpulan data yang digunakan sebagai data pendukung penelitian ini yaitu dengan melakukan wawancara kepada narasumber dengan mengajukan beberapa pertanyaan yang mendukung permasalahan yang akan diangkat, selain itu penelitian ini juga menggunakan kuesioner yang disebarkan kepada para content creator mengenai seberapa dibutuhkan nya aplikasi pencari kerja dibilang content creator dan juga penelitian ini menggunakan studi pustaka untuk mempelajari dan meneliti guna mendapatkan informasi seputar content creator.

Berikut adalah gambaran diagram alir sebagai panduan pada penelitian ini:

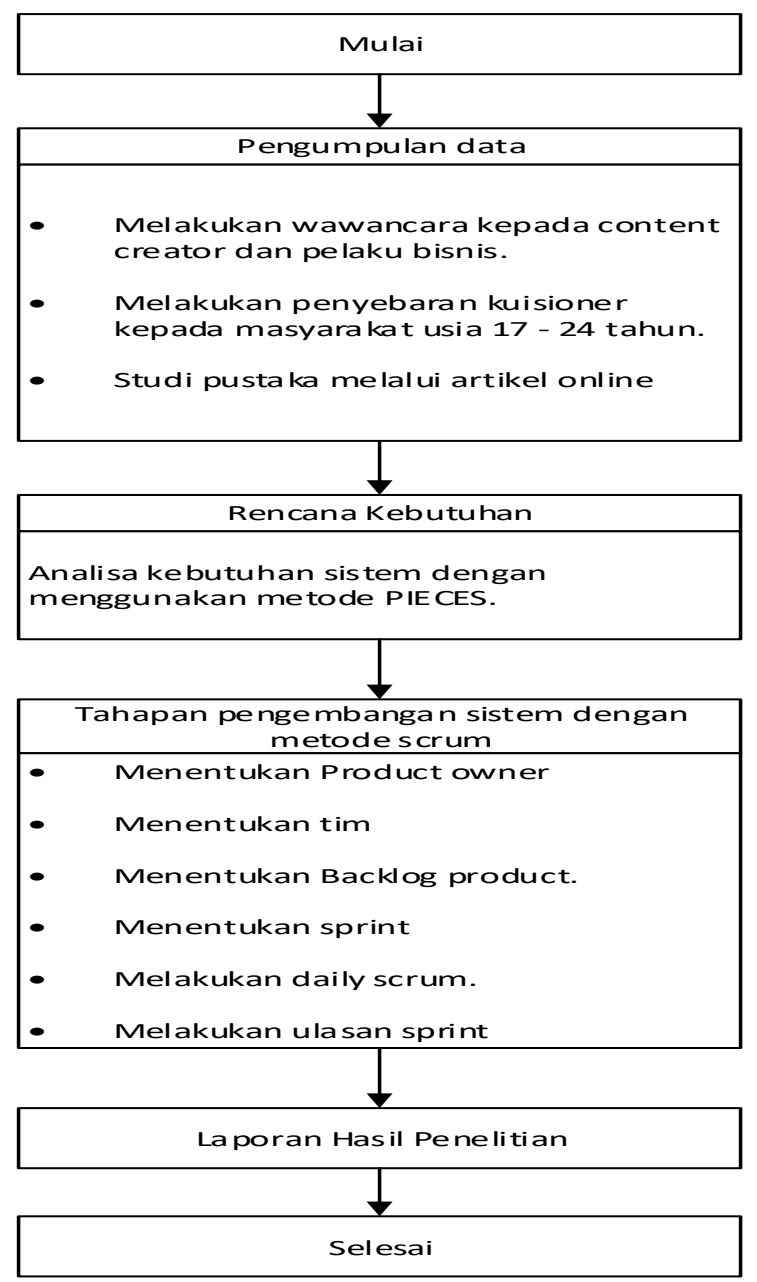

Gbr. 1 Diagram Alir Penelitian 


\section{HASIL DAN PEMBAHASAN}

\section{A. Analisa Sistem}

Saat ini jasa content creator sedang banyak dicari oleh perusahaan atau pebisnis untuk membantu mereka

Page | 164 dalam membuat konten guna memperkenalkan produk yang mereka miliki ataupun untuk branding perusahaan.

Ada beberapa cara yang dilakukan oleh perusahaan atau pemilik toko untuk mendapatkan seorang content creator saat ini, yaitu melalui LinkedIn, Kontenesia ataupun dengan mengandalkan jaringan pertemanan yang dimiliki. Berikut merupakan alur sistem berjalan dari cara yang sudah ada.

\section{Melalui Kontenesia}

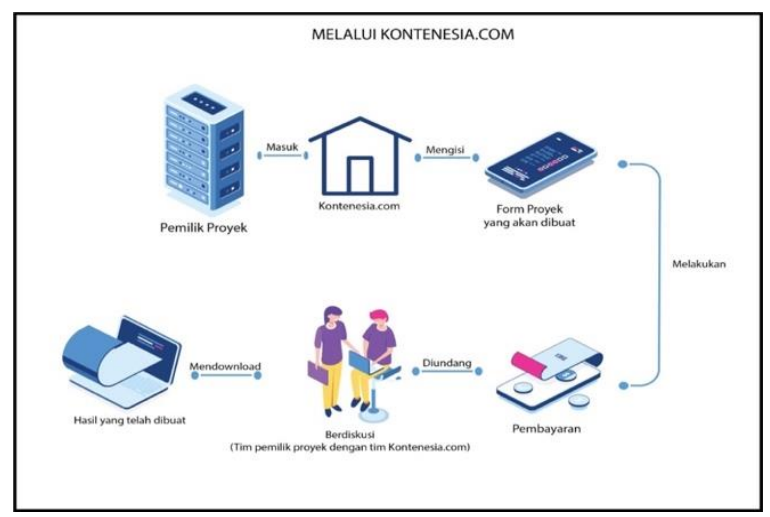

Gbr. 2 Alur Sistem Berjalan Melalui Kontenesia

Salah satu perusahaan yang pernah menggunakan jasa Kontenesia yaitu Cilsy Fiolution, Kontenesia membantu Cilsy Fiolution dalam membuat tulisan pada blog dan website. Tahapan yang harus dilakukan oleh Cilsy Fiolution untuk bisa menggunakan jasa Kontenesia yaitu :

- Tim Cilsy Fiolution membuka website Kontenesia, lalu registrasi data.

- Kemudian memilih layanan atau jasa yang akan digunakan.

- Lalu memberikan keterangan mengenai apa yang ingin dibuat dengan mengisi sebuah form.

- Kemudian tim Cilsy Fiolution harus melakukan pembayaran terlebih dahulu agar pesanannya bisa diproses oleh tim Kontenesia.

- Kemudian tim Cilsy Fiolution akan diundang kedalam sebuah grup untuk berdiskusi dengan tim Kontenseia mengenai projek yang akan dibuat.

- Setelah puas dengan hasil yang dikerjakan oleh tim Kontenesia, maka tim Cilsy Fiolution bisa mengunduh file yang berisikan pesanan yang diinginkan.

\section{Melalui LinkedIn}

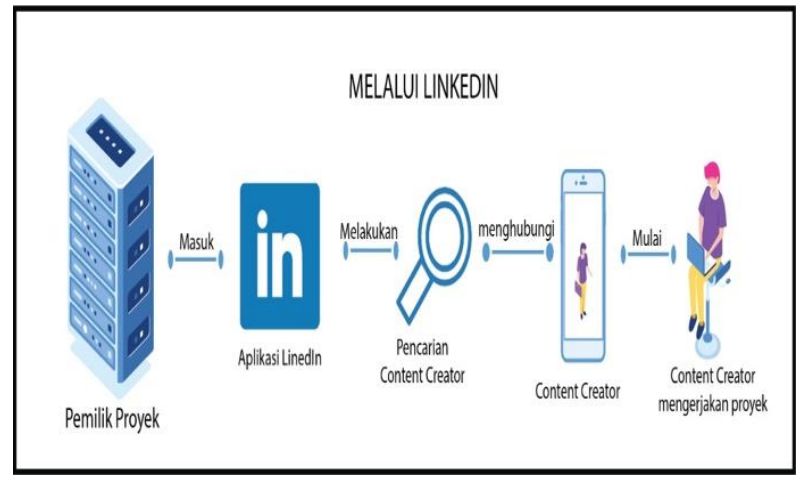

Gbr. 3 Alur Sistem Berjalan Melalui LinkedIn

Aplikasi LinkedIn juga merupakan salah satu platform yang biasa digunakan oleh narasumber yaitu Cilsy Fiolution dalam mencari jasa seorang content creator. Tahapan yang harus dilakukan untuk mendapatkan seorang content creator melalui LinkedIn yaitu :

- Tim Cilsy mengunduh aplikasi LinkedIn melalui smartphone, lalu register.

- Setelah masuk halaman utama, tim Cilsy kemudian mencari seorang content creator yang bisa diajak bekerja sama.

- Setelah content creator ditemukan, lalu tim Cilsy menghubungi content creator tersebut untuk membahas proyek yang akan dikerjakan.

3. Melalui Jaringan Pertemanan

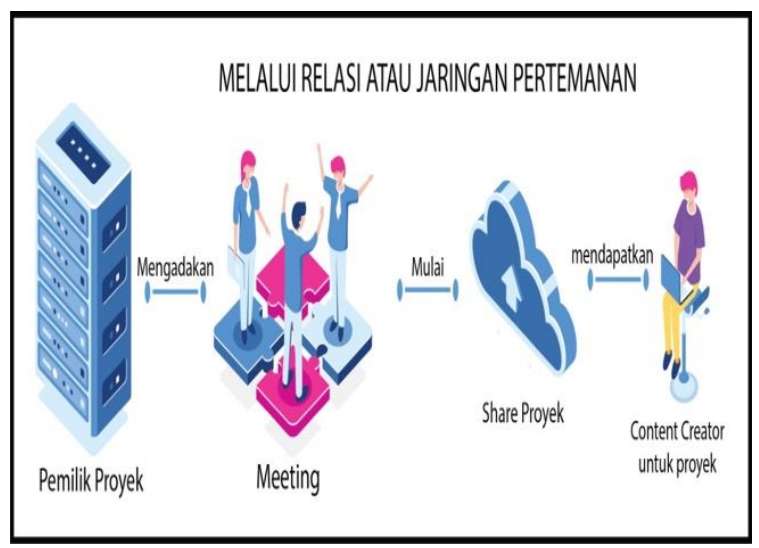

Gbr. 4 Alur Sistem Berjalan Melalui Jaringan Pertemanan

Alternatif lain yang dilakukan oleh tim Cilsy Fiolution dalam mencari seorang content creator yaitu dengan memanfaatkan jaringan pertemanan yang mereka miliki, hal ini bisa dilakukan apabila perusahaan atau pemilik toko memiliki relasi yang sangat luas. Tahapan yang dilalui, yaitu: 
- Cilsy mengadakan meeting dengan beberapa timnya untuk membahas projek yang akan dibuat.

- Lalu tim kecil tersebut menyebarkan berita melalui sosial media atau media komunikasi elektronik yang mereka miliki.

- Jika ada content creator yang berminat, mereka akan langsung menghubungi pihak perusahaan untuk membahas proyek yang akan dibuat.

Dari seluruh pilihan yang ada, ditemukan beberapa kendala atau masalah yang terjadi. Kemudian dari masalah tersebut dilakukan lah sebuah Analisa masalah dengan menggunakan metode PIECES. PIECES merupakan suatu kerangka kerja yang berguna untuk mengklasifikasikan permasalahan.

Berikut merupakan Analisa yang dilakukan:

TABEL 1

HASIL ANALISA MASALAH

\begin{tabular}{|c|c|c|}
\hline \multicolumn{3}{|c|}{ HASIL ANALISA MASALAH } \\
\hline $\begin{array}{l}\text { Jenis } \\
\text { Analisa }\end{array}$ & Kendala & Solusi \\
\hline Performance & $\begin{array}{l}\text { Seringkali konten } \\
\text { yang dibuat asal } \\
\text { atau tidak sesuai } \\
\text { dengan apa yang } \\
\text { diharapkan } \\
\text { apabila } \\
\text { mengandalkan } \\
\text { relasi atau } \\
\text { jaringan } \\
\text { pertemanan }\end{array}$ & $\begin{array}{l}\text { Dibuatkan } \\
\text { sebuah } \\
\text { halaman } \\
\text { portofolio } \\
\text { sang content } \\
\text { creator untuk } \\
\text { menjamin } \\
\text { hasil yang } \\
\text { diberikan }\end{array}$ \\
\hline \multirow[t]{2}{*}{ Information } & $\begin{array}{l}\text { Informasi tidak } \\
\text { tersebar secara } \\
\text { luas apabila hanya } \\
\text { mengandalkan } \\
\text { relasi atau } \\
\text { jaringan } \\
\text { pertemanan }\end{array}$ & \multirow{2}{*}{$\begin{array}{l}\text { Buatkan } \\
\text { website yang } \\
\text { bisa diakses } \\
\text { oleh siapapun, } \\
\text { dimanapun } \\
\text { dan kapanpun }\end{array}$} \\
\hline & $\begin{array}{l}\text { Content creator } \\
\text { sulit mendapatkan } \\
\text { informasi } \\
\text { mengenai suatu } \\
\text { proyek }\end{array}$ & \\
\hline Economic & $\begin{array}{l}\text { Biaya yang } \\
\text { dikeluarkan cukup } \\
\text { mahal apabila } \\
\text { bekerja sama } \\
\text { dengan } \\
\text { Kontenesia.Com } \\
\text { karena mereka } \\
\text { merupakan } \\
\text { sebuah agensi }\end{array}$ & $\begin{array}{l}\text { Dibuatkan } \\
\text { sistem seleksi } \\
\text { content creator } \\
\text { sehingga dapat } \\
\text { memilih } \\
\text { content } \\
\text { creator mana } \\
\text { yang sesuai } \\
\text { dengan budget } \\
\text { yang dimiliki }\end{array}$ \\
\hline Control & & \\
\hline
\end{tabular}

\begin{tabular}{|l|l|l|}
\hline \multirow{5}{*}{ Efficiency } & $\begin{array}{l}\text { Perusahaan, } \\
\text { pebisnis, } \\
\text { organisasi } \\
\text { ataupun } \\
\text { perseorangan } \\
\text { bekerja lebih } \\
\text { ekstra apabila } \\
\text { harus mencari } \\
\text { content creator } \\
\text { melalui LinkedIn }\end{array}$ & $\begin{array}{l}\text { Sistem } \\
\text { aplikasi dibuat } \\
\text { khusus untuk } \\
\text { mencari } \\
\text { content } \\
\text { creator }\end{array}$ \\
\hline Service & $\begin{array}{l}\text { Sulit untuk } \\
\text { mengetahui track } \\
\text { record content } \\
\text { creator }\end{array}$ & $\begin{array}{l}\text { Dibuatkan } \\
\text { riwayat } \\
\text { pekerjaan } \\
\text { yang } \\
\text { dilakukan oleh } \\
\text { content } \\
\text { creator }\end{array}$ \\
\hline
\end{tabular}

\section{B. Product Backlog}

Langkah pertama dalam mengembangkan sistem menggunakan metode scrum yaitu membuat backlog product. Berikut product backlog sistem informasi pencari kerja content creator untuk sosial media:

TABEL 2

$B A C K L O G$ PRODUCT

\begin{tabular}{|c|c|c|c|}
\hline $\begin{array}{l}\mathbf{N} \\
\mathbf{o}\end{array}$ & $\begin{array}{c}\text { Judul } \\
\text { Backlog }\end{array}$ & Deskripsi & Sprint \\
\hline 1 & $\begin{array}{l}\text { Master } \\
\text { Kategori }\end{array}$ & $\begin{array}{l}\text { Membuat sistem } \\
\text { CRUD untuk master } \\
\text { kategori }\end{array}$ & $\begin{array}{c}\text { Sprint } \\
1\end{array}$ \\
\hline 2 & $\begin{array}{l}\text { Master } \\
\text { Artikel }\end{array}$ & $\begin{array}{l}\text { Membuat sistem } \\
\text { CRUD untuk master } \\
\text { artikel }\end{array}$ & $\begin{array}{c}\text { Sprint } \\
1\end{array}$ \\
\hline 3 & $\begin{array}{l}\text { Master } \\
\text { Pesan }\end{array}$ & $\begin{array}{l}\text { Membuat sistem } \\
\text { CRUD untuk master } \\
\text { pesan }\end{array}$ & $\begin{array}{c}\text { Sprint } \\
1\end{array}$ \\
\hline 4 & $\begin{array}{l}\text { Daftar } \\
\text { Transaksi }\end{array}$ & $\begin{array}{l}\text { Membuat sistem } \\
\text { untuk menampilkan } \\
\text { daftar transaksi } \\
\text { proyek user dengan } \\
\text { fitur update dan } \\
\text { delete }\end{array}$ & $\begin{array}{c}\text { Sprint } \\
2\end{array}$ \\
\hline 5 & $\begin{array}{l}\text { Transaksi } \\
\text { Input } \\
\text { Proyek }\end{array}$ & $\begin{array}{l}\text { Membuat sistem } \\
\text { CRUD untuk } \\
\text { transaksi input data } \\
\text { proyek }\end{array}$ & $\begin{array}{c}\text { Sprint } \\
3\end{array}$ \\
\hline 6 & $\begin{array}{l}\text { Transaksi } \\
\text { Apply } \\
\text { Proyek }\end{array}$ & $\begin{array}{l}\text { Membuat sistem } \\
\text { transaksi apply } \\
\text { proyek }\end{array}$ & $\begin{array}{c}\text { Sprint } \\
3\end{array}$ \\
\hline 7 & $\begin{array}{l}\text { Transaksi } \\
\text { Seleksi }\end{array}$ & $\begin{array}{l}\text { Membuat sistem } \\
\text { CRUD untuk } \\
\text { menyeleksi lamaran } \\
\text { atau kontribusi yang } \\
\text { telah diinput kedalam } \\
\text { proyek }\end{array}$ & $\begin{array}{c}\text { Sprint } \\
3\end{array}$ \\
\hline
\end{tabular}




\begin{tabular}{|c|c|c|c|c|}
\hline \multirow{11}{*}{ Page | 166} & 8 & Profil User & $\begin{array}{l}\text { Membuat sistem } \\
\text { CRUD untuk profil } \\
\text { user }\end{array}$ & $\begin{array}{c}\text { Sprint } \\
4\end{array}$ \\
\hline & 9 & $\begin{array}{l}\text { Transaksi } \\
\text { Dompet }\end{array}$ & $\begin{array}{l}\text { Membuat sistem } \\
\text { CRUD untuk } \\
\text { transaksi pembayaran } \\
\text { kontributor yang } \\
\text { telah berpartisipasi } \\
\text { dalam proyek } \\
\end{array}$ & $\begin{array}{c}\text { Sprint } \\
5\end{array}$ \\
\hline & 10 & $\begin{array}{l}\text { Tampilan } \\
\text { Dashboard }\end{array}$ & $\begin{array}{l}\text { Membuat tampilan } \\
\text { dashboard untuk user }\end{array}$ & $\begin{array}{c}\text { Sprint } \\
6\end{array}$ \\
\hline & 11 & $\begin{array}{l}\text { Tampilan } \\
\text { Proyek }\end{array}$ & $\begin{array}{l}\text { Membuat tampilan } \\
\text { daftar mengenai } \\
\text { proyek yang telah } \\
\text { dibuat } \\
\end{array}$ & $\begin{array}{c}\text { Sprint } \\
7\end{array}$ \\
\hline & 12 & $\begin{array}{l}\text { Tampilan } \\
\text { Kontribusi }\end{array}$ & $\begin{array}{l}\text { Membuat tampilan } \\
\text { daftar mengenai } \\
\text { kontribusi apa saja } \\
\text { yang telah dilakukan }\end{array}$ & $\begin{array}{c}\text { Sprint } \\
7\end{array}$ \\
\hline & 13 & $\begin{array}{l}\text { Tampilan } \\
\text { Karya }\end{array}$ & $\begin{array}{l}\text { Membuat tampilan } \\
\text { daftar karya apa saja } \\
\text { yang telah dibuat }\end{array}$ & $\begin{array}{c}\text { Sprint } \\
7\end{array}$ \\
\hline & 14 & Laporan & Membuat report & $\begin{array}{c}\text { Sprint } \\
8 \\
\end{array}$ \\
\hline & 15 & Data User & $\begin{array}{l}\text { Membuat sistem } \\
\text { untuk pengaturan } \\
\text { user }\end{array}$ & $\begin{array}{l}\text { Sprint } \\
9\end{array}$ \\
\hline & 16 & Footer & $\begin{array}{l}\text { Membuat footer } \\
\text { (tentang kami, FAQ, } \\
\text { testimoni, kontrak } \\
\text { kami, kontak) }\end{array}$ & $\begin{array}{c}\text { Sprint } \\
10\end{array}$ \\
\hline & 17 & $\begin{array}{l}\text { Login dan } \\
\text { Register }\end{array}$ & $\begin{array}{l}\text { Membuat sistem } \\
\text { login dan Register }\end{array}$ & $\begin{array}{c}\text { Sprint } \\
11\end{array}$ \\
\hline & 18 & $\begin{array}{l}\text { Ubah } \\
\text { Password }\end{array}$ & $\begin{array}{l}\text { Membuat ubah } \\
\text { password }\end{array}$ & $\begin{array}{c}\text { Sprint } \\
11\end{array}$ \\
\hline
\end{tabular}

\section{Alur Aplikasi Sistem PINDA}

Pada penelitian ini menghasilkan sebuah sistem aplikasi baru berbasis web yang bertujuan untuk memberikan informasi mengenai pekerjaan atau proyek seputar content creator untuk sosial media sehingga pemilik proyek bisa memasukkan proyek yang ingin dibuat dan content creator bisa mengajukan diri untuk bergabung kedalam proyek.

Berikut merupakan alur proses yang harus dilakukan apabila menggunakan sistem aplikasi PINDA :

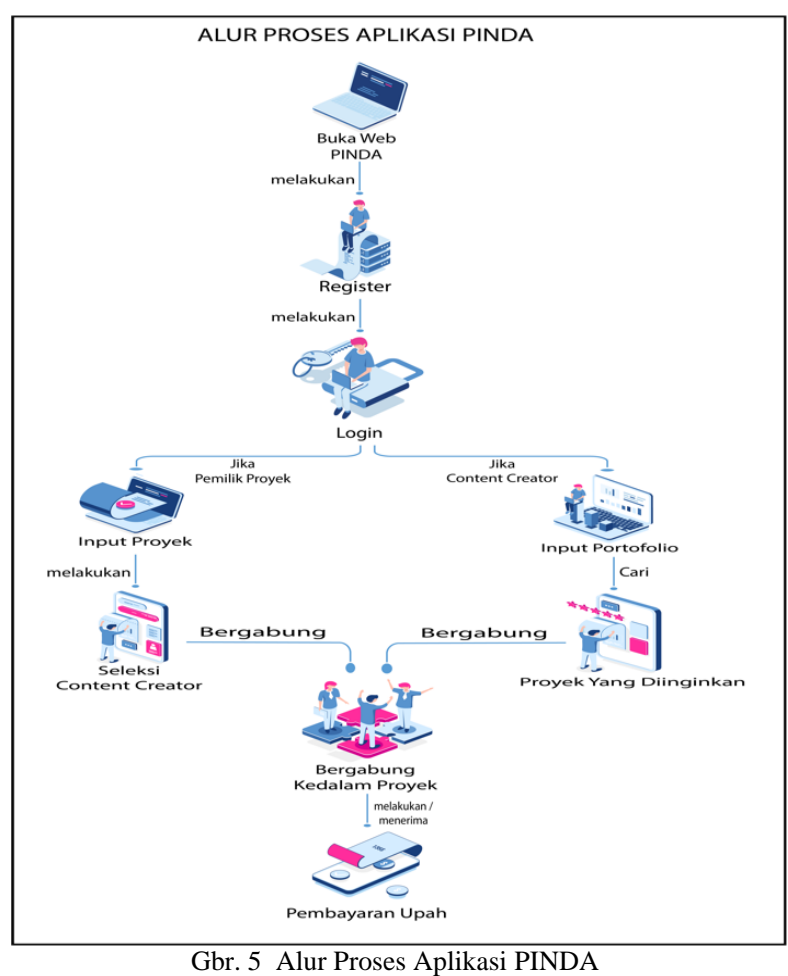

Urutan langkah yang harus dilakukan yaitu :

- Buka situs PINDA melalui web browser

- Setelah berkunjung ke web PINDA, lakukan registrasi terlebih dahulu apabila belum memiliki akun

- Setelah memiliki akun, lakukan login

- Lalu apabila user bertindak sebagai seorang content creator maka langkah awal yang dilakukan yaitu input portofolio, sedangkan apabila sebagai pemilik proyek bisa langsung input proyek yang akan digunakan

- Langkah selanjutnya sebagai content creator yaitu cari proyek yang diminati, sedangkan apabila sebagai pemilik proyek bisa melakukan seleksi content creator yang ingin bergabung kedalam proyek

- Setelah content creator dan pemilik proyek saling merasa cocok, mereka akan bergabung kedalam proyek tersebut untuk mulai mengerjakan proyek

- Setelah proyek berhasil dikerjakan, maka pemilik proyek bisa melakukan pembayaran dan content creator bisa mendapatkan upah atas pekerjaan yang dilakukannya.

\section{Interface Sistem}

Berikut ini beberapa contoh hasil tampilan dari aplikasi sistem PINDA. 
Gambar 6 merupakan tampilan aplikasi pada halaman detail project. Halaman ini digunakan oleh user untuk melihat proyek apa saja yang sedang berjalan, sehingga para content creator bisa menawarkan diri untuk bergabung kedalam proyek dan disisi lain pemilik proyek bisa melakukan seleksi calon content creator yang berhak bergabung kedalam proyek.

Halaman ini dapat diakses apabila sebelumnya pemilik proyek sudah memasukkan proyek yang akan dibuat dengan tujuan mencari content creator.

Pada halaman ini terdapat penjelasan mengenai kategori proyek, tagline proyek, deskripsi proyek, penjelasan desain dan persyaratan untuk bisa bergabung kedalam proyek, selain itu pada halaman ini juga terdapat tombol download untuk content creator apabila pemilik proyek memiliki contoh desain atau dokumen lain yang berkaitan dengan proyek yang diusung.

Pada bagian atas halaman juga terdapat status proyek berjalan, batas waktu pengerjaan, nilai pembayaran dan jumlah anggota yang dibutuhkan sehingga semua informasi yang dibutuhkan oleh content creator sudah tersedia jelas dan transparan.

Selain itu, pada bagian kanan halaman terdapat tombol bergabung kedalam proyek untuk content creator mengajukan diri kedalam proyek, lalu ada tombol submit desain untuk mengupload desain yang telah dibuat atau content creator juga bisa memberikan ide atau gagasan untuk proyek yang sedang berjalan dengan menekan tombol berikan ide dan saran.

Kemudian pada bagian bawah halaman terdapat informasi terkait dengan siapa saja content creator yang sudah memberikan ide untuk proyek tersebut, lalu ditab kedua terdapat informasi mengenai siapa saja yang tergabung kedalam proyek tersebut dan ditab terakhir terdapat informasi berkaitan dengan ide atau saran apa saja yang masuk untuk proyek tersebut.

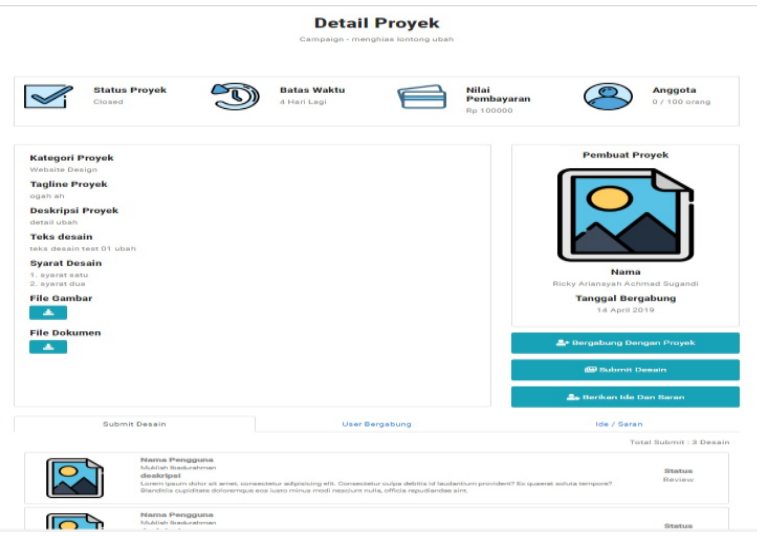

Gbr. 6 Tampilan Halaman Detail Proyek

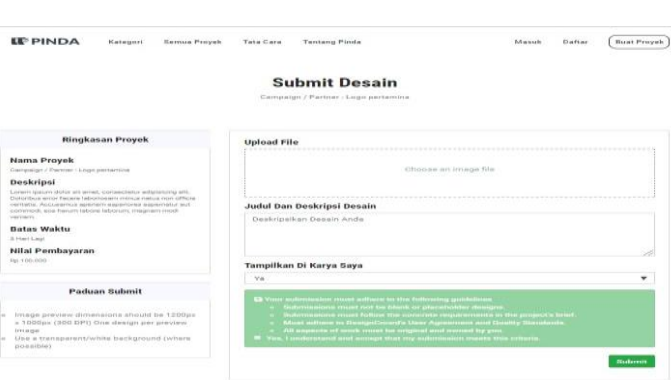

Gbr. 7 Tampilan Halaman Submit Desain

Gambar 7 merupakan tampilan dari halaman submit desain, halaman ini dapat diakses oleh content creator apabila ingin memasukkan desain yang telah dibuat kedalam suatu proyek yang sedang ia kerjakan, selain itu gambar atau desain yang telah diupload oleh content creator bisa ditampilkan kedalam halaman portofolio sebagai lampiran bahwa ia pernah mengerjakan proyek tersebut.

Pada halaman ini terdapat beberapa informasi seperti pada bagian kiri halaman terdapat informasi mengenai nama proyek atas desain tersebut, deskripsi mengenai proyek atas desain tersebut, batas waktu pengerjaan dan upah yang diterima oleh content creator atas desain tersebut.

Lalu pada sisi kanan halaman terdapat ruang untuk upload desain, judul dan deskripsi atas desain tersebut dan juga persetujuan apakah desain tersebut mau ditampilkan pada halaman portofolio atau tidak, kemudian terdapat ketentuan atau notifikasi yang berkaitan dengan proyek yang sedang berjalan, sehingga semua informasi yang berkaitan dengan desain tersebut dapat diketahui oleh content creator.

Apabila content creator sudah memahami betul mengenai proyek tersebut, maka content creator bisa langsung menekan tombol submit yang terdapat pada bagian kanan bawah halaman.

\section{KESIMPULAN}

Adapun kesimpulan dari penelitian ini, yaitu:

1. Sistem aplikasi ini dapat digunakan oleh seorang content creator untuk mencari dan mengajukan diri kedalam sebuah proyek yang sesuai dengan bidang keahlian yang mereka miliki.

2. Sistem aplikasi ini juga dapat digunakan oleh perusahaan ataupun pemilik toko atau pebisnis untuk membantu mereka dalam mencari jasa seorang content creator guna membantu mereka dalam membuat konten yang menarik. 


\section{UCAPAN TERIMA KASIH}

Terima kasih kepada Universitas Mercu Buana yang telah memberikan terhadap peneliatian ini. Kepada Ibu

Page|168 Inge Handriani yang telah memberikan supportnya dalam proses penyelesaian penelitian ini.

\section{REFERENSI}

[1] M. F. 4 Soni Akhmad Nulhaqim1, R. Dudy Heryadi2, Ramadhan Pancasilawan3, "Peranan Perguruan Tinggi Dalam Meningkatkan Kualitas Pendidikan Di Indonesia Untuk Menghadapi Asean Community 201533," Univ. Padjadjaran, Vol. 6, P. 198, 2015.

[2] R. Nurul, T. Wahyuni, And K. Monika, "( The Impact Of Education On Income Inequality Among Indonesian Workers )," Vol. 11, No. 1, 2016.

[3] F. Syahdan, "Hubungan Antara Keterampilan Kerja Dengan Produktivitas Kerja,” Vol. 5, No. 1, Pp. 1-10, 2017.

[4] M. Lubiana And Dh. Achmad Fauzi, "Pengaruh Social Media Marketing Terhadap Keputusan Pembelian ( Survei Online Pada Mahasiswa Sarjana Jurusan Ilmu Administrasi Bisnis Angkatan 2014 / 2015 Fakultas Ilmu Administrasi Universitas Brawijaya Yang Membeli Starbucks," J. Adm. Bisnis, Vol. 58, No. 1, Pp. 190-199, 2018.

[5] A. Sundawa And W. Trigartanti, "Fenomena Content Creator Di Era Digital Content Creator Phenomenon In Digital Era," Pp. 438-443, 2015.

[6] H. Aulawi, M. A. Ramdhani, C. Slamet, H. Ainissyifa, And W. Darmalaksana, "Functional Need Analysis Of Knowledge Portal Design In Higher Education Institution," Int. Soft Comput., Vol. 12, No. 2, Pp. 132-141, 2017.

[7] Y. Tresnawati And K. Prasetyo, "Pemetaan Konten Promosi Digital Bisnis Kuliner Kika's Catering Di Media Sosial," Profesi Humas J. Ilm. Ilmu Hub. Masy., Vol. 3, No. 1, P. 102, 2018.

[8] J. Dama And I. W. . Ogi, "Pengaruh Inovasi Terhadap Dan Kreativitas Terhadap Kinerja Karyawan Pada Pt Bank Mandiri (Persero) Tbk. Manado,” Vol. 6, No. 1, Pp. 41-50, 2018.

[9] F. Y. Permana, "Mempertahankan Pasar Media Cetak Melalui Konten Augmented Reality / Ar," Channel, Vol. 5, No. 2, Pp. 77-90, 2017.

[10] T. Ferdiana, I. Wirasari, And S. Nurbani, “Analisis Strategi Kreatif Iklan Bukalapak Di Media Sosial Bukalapak," Vol. 4, No. 6, Pp. 67-72, 2017.

[11] I. Handriani, A. N. S. Sidik, A. Multazam, And I. Wijaya, "Vol 1 No.2 Edisi 1 Januari 2019 Http://Jurnal.Ensiklopediaku.Org Ensiklopedia Of Journal," Vol. 1, No. 2, Pp. 117-125, 2019

[12] S. T. D. N. Ismiyanti, L. Fitriani, And R. Kurniawati, "Pengembangan Aplikasi Lowongan Kerja Career Development Center Di Sekolah Tinggi Teknologi Garut," J. Algoritm. Sekol. Tinggi Teknol. Garut, Pp. 415-420, 2017.

[13] M. Safitri, A. Novianti, And A. Noviriandini, "Sistem Informasi Lowongan Kerja Berbasis Web," J. Pilar Nusa Mandiri, Vol. 14, No. 1, Pp. 49-54, 2018.

[14] M. A. Dewi And R. Andriani, "Perancangan Sistem Monitoring Inventory Control Cleaning Equipment Dan Chemical Pada Pt Explore Global Solution," Ultim. Infosys, Vol. Viii, No. 2, Pp. 112-117, 2017.

[15] Y. Asbar And M. A. Saptari, "Analisa Dalam Mengukur Kualitas Pelayanan Terhadap Kepuasan Konsumen Menggunakan Metode Pieces," J. Visioner Strateg., Vol. 6, No. 2, Pp. 39-47, 2018. 